\title{
THE SPATIO-TEMPORAL VARIATION OF SEISMICITY BEFORE THE 1971 SAN FERNANDO EARTHQUAKE, CALIFORNIA
}

\author{
Mizuho Ishida* and Hiroo Kanamori
}

Seismological Laboratory, California Institute of Technology, Pasadena, California 91125 *on leave from National Research Center for Disaster Prevention, Tokyo, Japan

Abstract. The spatio-temporal variation of seismicity prior to the 1971 San Fernando, California, earthquake is studied for the area within $35 \mathrm{~km}$ of the epicenter. During the period from 1932 to 1961 , the seismicity in this area was relatively low and random. A remarkable NE-SW trending alignment of activity occurred during the period from 1961 to 1964 , the period corresponding to the inferred onset of the Palmdale uplift. During the period from 1965 to 1968, the seismicity around the epicentral area became extremely low; no event was located within $13 \mathrm{~km}$ from the epicenter. During the period from 1969 to the occurrence of the San Fernando earthquake, activity around the epicentral area increased. This activity may be considered to be foreshock activity in a broad sense.

The spatio-temporal variation of selsmicity before major earthquakes has been studied by many investigators, among others Inouye (1965), Mog1 (1969), Kelleher and Savino (1975), Wesson and EIlsworth (1973), McNa11y (1976), Sekiya (1976, 1977), Engdah1 and Kiss1inger (1977) and Ohtake (1976).

This paper presents such a study for the 1971 San Fernando earthquake $\left(M_{L}=6.4\right)$, one of the largest events in Southern California. It occurred within the seismographic network of the California Institute of Technology and reasonably accurate selsmicity data are available prior to its occurrence. In a recent paper, Brady (1976) Investigated the seismicity pattern prior to the 1971 San Fernando earthquake to test his inclusion theory of earthquakes. The present paper includes the seismicity data for a larger area and a longer time period than in his study. We will focus our attention on the temporal variation of the number of events within a circle of diameter $70 \mathrm{~km}$ around the epicenter of the 1971 San Fernando earthquake. This diameter is about five times the inferred fault dimension of the San Fernando earthquake. The source of the data is Hileman et al. (1973).

First we compute the distance $L$ between the epicenter of the mainshock and each individual event before the San Fernando earthquake. Figure 1 shows $\mathrm{L}$ for all earthquakes within $20 \mathrm{~km}$ of the epicenter of the San Fernando earthquake that occurred prior to the mainshock. Although the lower limit of the magnitude of these events is about 1 to 1.5 , the coverage is complete only for $M_{L} \geq 2.5$. The length of the ordinate is taken proportional to $\mathrm{L}^{2}$ so that the spatial density of the events is invariant in the mapping. Notable features in this plot are: (1) a relatively random and low activity prior to 1961 (Period I); (2) a relatively high

Copyright 1977 by the American Geophysical Union. activity during the period from 1961 to 1964 (Period II); (3) nearly complete absence of activity within $13 \mathrm{~km}$ from the epicenter during the period from 1965 to 1968 (Period III); (4) a resumption of activity around the epicenter during the period from 1969 to the occurrence of the San Fernando earthquake (Period IV). Although the detection capability of the network and the accuracy of the event location are not uniform during the entire period shown in Figure 1, this pattern is probably real, at least qualitatively. The spatial distributions of the events during the respective periods are shown in Figure 2. During Period I, the events are more or less randomly distributed. A notable NE-SW trending alignment of events is seen during Period II. This alignment is noted by Whitcomb et al. (1973a) and is called the Palmdale-Point Dume line. This line colncides with the western edge of the fault plane of the San Fernando earthquake. Brady (1976) interpreted the central part of this activity as "the primary inclusion zone of the impending fallure". During Period III, the epicentral area became completely quiet. This low activity was also noted earlier by Brady who related it with "the area surrounding the primary inclusion zone". During Period IV, Increase of activity near the epicenter of the San Fernando earthquake is seen. This activity may be considered to be foreshock activity in a broad sense. The event nearest the San Fernando epicenter occurred on September 28, 1970. Although this pattern and the occurrence of the San Fernando earthquake may be mere coincidence, the result may suggest a causal relation. A pattern similar to this has been reported by Inouye (1965), Mogi (1969) and more recently by Kelleher and Savino (1975), Sekiya (1976, 1977) and Ohtake (1976), although the details and the clarity of the pattern vary from event to event. Scholz et al. (1973) suggest a pattern of seismicity change similar to this on the basis of the dilatancy model.

It is interesting to note that the period of the alignment of events corresponds to the inferred beginning of the Palmdale uplift (Castle et al., 1976) and the period of the "foreshock", activity corresponds approximately

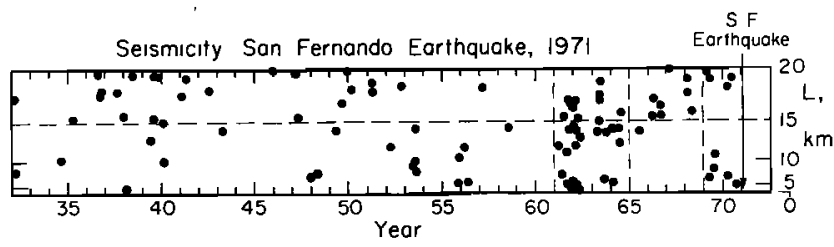

Fig. 1. The distance $\mathrm{L}$ between the epicenter of the 1971 San Fernando earthquake and the events prior to it as a function of year. Events within $20 \mathrm{~km}$ from the epicenter are plotted. 

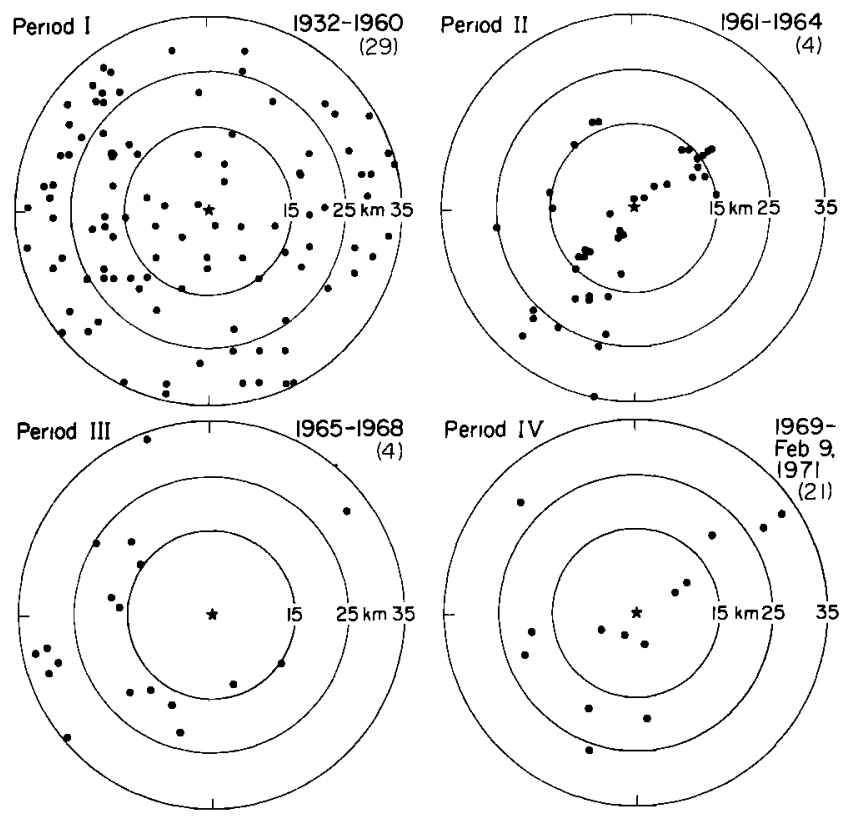

Fig. 2. Spatial distribution of epicenters for four periods:

I (1932 to 1960$)$

II (1961 to 1964$)$

III (1965 to 1968)

IV (1969 to February, 1971)

The asterisk is the epicenter of the 1971 San Fernando earthquake $\left(34^{\circ} 24.7^{\prime} \mathrm{N} ; 118^{\circ} 24.0^{\prime} \mathrm{W}\right)$.

The number in parentheses denotes the number of years in the respective period.

to the time of a localized episodic tilting precursory to the San Fernando earthquake (Castle et a1., 1974; Thatcher, 1976).

Whitcomb et al. (1973b) reported a velocity bay prior to the San Fernando earthquake and interpreted it in terms of the dilatancy model. However, the timing and the spatial extent of the velocity anomaly do not correlate with the present result in an obvious way.

Acknowledgment. We thank Robert Geller and Seth Stein for reading the manuscript and making useful corments for improvements. Mizuho Ishida was supported by a fellowship from the Science and Technology Agency of Japan. This research was sponsored by U.S. Geological Survey Contract No. 14-08-0001-15893. Contribution No. 2912, Diviston of Geological and Planetary Sciences, California Institute of Technology, Pasadena, California 91125.

\section{References}

Brady, B. T., Theory of earthquakes - IV General implications for earthquake prediction, Pure and Appl. Geophys., 114, 1031-1082, 1976.
Castle, R. 0., J. N. Alt, J. C. Savage and E. I. Balaz, Elevation changes preceding the San Fernando earthquake of February 9, 1971, Geology, 2, 61-66, 1974.

Castle, R. 0., J. P. Church and M. R. Elliott, Aseismic uplift in Southern California, Science, 192, 251-253, 1976.

Engdah1, E. R., and C. Kisslinger, Phenomena precursory to a magnitude 5 earthquake in the central Aleutian Islands, abstract, E丹S, 58, $433,1977$.

Hileman, J. A., C. R. Allen and J. M. Nordquist, Seismicity of the Southern California region 1 January 1932 to 31 December 1972, Seismological Laboratory, California Institute of Technology, Pasadena, California, pp. 83,1973.

Inouye, $W .$, On the seismicity in the epicentral region and its neighborhood before the Nigata earthquake, Kenshin Jiho, 29, 139-144, 1965 (in Japanese).

Kelleher, J. and J. Savino, Distribution of seismicity before large strike-slip and thrusttype earthquakes, J. Geophys. Res., 80, 260$271,1975$.

McNally, K., Spatial and temporal and mechanistic character in earthquake occurrence, $\mathrm{Ph} . \mathrm{D}$. Dissertation, University of California, Berkeley, 140 pp., 1976.

Mogi, K., Some features of recent seismic activity in and near Japan (2) Activity before and after great earthquakes, Bull. Earthquake Res. Inst. Tokyo Univ. , 47, 395-417, 1969.

Ohtake, M., Search for precursors of the 1974 Izu-Hanto-oki earthquake, Japan, Pure and App1. Geophys., 114, 1083-1093, 1976.

Scholz, C., L. Sykes and Y. Aggarwal, A physical basis for earthquake prediction, Science, 181, 803-810, 1973.

Sekiya, H., The seismicity preceding earthquakes and its significance to earthquake prediction, Zisin, 29, 299-311, 1976 (in Japanese).

Sekiya, H., Anomalous seismic activity and earthquake prediction, J. Phys. Earth, 25, in press, 1977.

Thatcher, w., Episodic strain accumulation in Southern California, Science, 194, 691-695, 1976.

Wesson, R., and W. Ellsworth, Seismicity preceding moderate earthquakes in California, J. Geophys. Res., 78, 8527-8546, 1973.

Whitcomb, J. H., C. R. Allen, J. D. Garmany and J. A. Hileman, San Fernando earthquake series, 1971: Focal mechanisms and tectonics, Rev. Geophys. Space Phys., 11, 693-730, 1973 a.

Whitcomb, J., J. Garmany and D. Anderson, Earthquake prediction: Variation of seismic velocities before the San Fernando earthquake, Science, 180, 632-635, $1973 \mathrm{~b}$.

(Recieved June 1, 1977 : accepted June 20, 1977.) 